\title{
Adaptability and stability of maize landrace varieties
}

\section{Adaptabilidade e estabilidade de variedades de milho crioulo}

\author{
Raquel Barboza Reis de Oliveira'; Rosângela Maria Pinto Moreira²; \\ Josué Maldonado Ferreira ${ }^{2 *}$
}

\begin{abstract}
Maize landrace varieties are known to be adaptable to different environmental conditions. The objective of this work was to estimate and compare adaptability and stability parameters of 12 maize landrace varieties during two cycles of recurrent selection. The study used grain yield data from eight experiments in the first selection cycle (Group I) and seven experiments in the second cycle (Group II). The experiments were conducted in Paraná and Santa Catarina states. Each experiment evaluated 12 maize landrace varieties and one control variety, BR106. The experiments involved a randomized complete block design in which four methodologies were used to analyze variety stability and adaptability. The majority of the maize landraces assessed were competitive with the control BR 106 in the environments studied. Different adaptability and stability outcomes were verified for both groups. The varieties Macaco, Amarelão and Carioca, from Group I, and Palha Roxa, Amarelão and Astequinha Sabugo Fino, from Group II, showed superior average grain yield, general adaptability and stability.
\end{abstract}

Key words: Zea mays, genotypes x environments interaction, family farm, participatory breeding

\section{Resumo}

As variedades de milho crioulo são tidas como adaptadas a diferentes condições ambientais. O objetivo deste trabalho foi estimar e comparar os parâmetros de adaptabilidade e estabilidade de 12 variedades de milho crioulo em dois ciclos de seleção recorrente. Foram utilizados dados de produtividade de grãos referentes a oito experimentos com variedades crioulas no primeiro ciclo de melhoramento (Grupo I) e sete experimentos no segundo ciclo (Grupo II), instalados no Estado do Paraná e Santa Catarina. Cada experimento avaliou 12 variedades de milho crioulo e a testemunha BR106. Os experimentos foram instalados segundo o delineamento em blocos completamente casualizados, sendo empregados quatro procedimentos para analisar a estabilidade e adaptabilidade das variedades. A maioria das variedades de milho crioulo avaliadas foram competitivas em relação à cultivar BR 106 nos ambientes estudados. Diferentes respostas foram observadas quanto à adaptabilidade e estabilidade nos dois grupos, para os diferentes métodos considerados. As variedades Macaco, Amarelão e Carioca, no Grupo I, e Palha Roxa, Amarelão e Astequinha Sabugo Fino, no Grupo II, apresentaram bom desempenho, adaptabilidade ampla e comportamento previsível.

Palavras-chave: Zea mays, interação genótipos x ambientes, agricultura familiar, melhoramento participativo

\footnotetext{
${ }^{1}$ Bióloga, M.e em Genética e Biologia Molecular, Universidade Estadual de Londrina, UEL, Londrina, PR. E-mail: raquelbarbozabio@yahoo.com.br

${ }^{2}$ Eng $^{\text {os }}$ Agrros , Profs. Drs. da UEL, Londrina, PR. E-mail: rosang@uel.br; josuemf@uel.br

* Autor para correspondência
} 


\section{Introduction}

Maize landrace varieties have been grown and maintained by several generations of family farmers. These varieties have traits, for example, genes that confer resistance to biotic and abiotic factors (ARAÚJO; NASS, 2002), good husking, and good potential grain yield, mainly in environments with low or no technology (ALMEKINDERS; LOUWAARS; BRUIJIN, 1994), that can be explored by breeding programs.

The wide genetic variability of maize landraces is considered the main reason for their adaptability to different environments (mainly rustic growing conditions) (CECCARELLI, 1994; PATERNIANI; NASS; SANTOS, 2000). Nevertheless, although landrace varieties are an important source of adaptability alleles, there is limited information in the current literature about adaptability and stability studies on them.

Adaptability and stability studies, which provide a detailed description of a genotype's performance under different environmental conditions, identify genotypes with phenotypic stability. They guarantee thus recommendations for the cultivar processes (CRUZ; REGAZZI; CARNEIRO, 2004; HAMAWAKI; SANTOS, 2003).

Several methods of performing adaptability and stability studies can be found in the literature, and studies of release cultivars have been performed to compare their efficiencies (CARGNELUTTI FILHO et al., 2007; FARIAS et al., 1997; MAURO et al., 2000). The methods proposed by Eberhart and Russell (1966) and Cruz, Torres e Vencovsky (1989) employ a linear regression analysis and have been widely used. The method proposed by Lin and Binns (1988) consists of a non-parametric analysis and, although not extensively discussed in the literature, is simpler and addresses the limitations of a linear regression analysis (MURAKAMI et al., 2004; SCAPIM et al., 2000).

Annicchiarico (1992) proposed a reliability index, which is based on the environmental mean deviation, for determining whether to adopt a particular genotype. Schmildt and Cruz (2005) stress that this reliability index is also a general or wide adaptability estimate, as presented in Eberhart and Russell (1966). Cruz, Regazzi e Carneiro (2004) emphasize that some methods are complementary while others are optional, although it is possible to combine different methods. Overall, which maize cultivars will be recommended will depend on the adaptability and stability method the researcher employed (CARGNELUTTI FILHO et al., 2007).

The objective of this work was to estimate and compare adaptability and stability parameters of 12 maize landraces during two cycles of recurrent selection.

\section{Material and Methods}

This study used grain yield data obtained in 15 experiments on 12 maize landrace varieties and one control variety, cultivar BR106. Trials were divided into group I (landraces in the first half-sib selection cycle) and group II (landraces in the second half-sib selection cycle). The group I trials were performed in 8 environments and the group II trials in 7 (Table 1). Trials were carried out on the family agricultural properties that have participated in the Participatory Breeding Program of Maize Landrace (FERREIRA et al., 2006). The conventional maize farming system was only adopted in the trial conducted in Londrina.

Trials were set in randomized complete blocks (4 replications) in plots with $4.00 \mathrm{~m}$ long rows $1.00 \mathrm{~m}$ apart, with $0.20 \mathrm{~m}$ between each plant. Grain yield data $\left(\mathrm{tha}^{-1}\right)$ were adjusted to 135 grams of water per kilogram of grain and to ideal standards according to the methodology presented in J. B. Miranda Filho (VENCOVSKY; BARRIGA, 1992).

The data from each experiment were analyzed using ANOVA tests, and for the joint analyses, the residual mean squares homogeneity for each group was verified (PIMENTEL-GOMES, 2000). In 
these analyses, treatments were considered as fixed model effects and environments and blocks in the environments were treated as random model effects (CRUZ; REGAZZI; CARNEIRO, 2004). Joint and individual trial analysis of variance tests were carried out using the SAS GLM procedure (SAS Institute Inc., 2005). The means of the varieties from each experiment were clustered using the Scott-Knott test at $\mathrm{p} \leq 0.05$. The Tukey test was used to compare general means among varieties in each group, using the treatments $\mathrm{x}$ environments interaction means square (PIMENTEL-GOMES, 2000).

Table 1. Crop years and cities for trials groups I and II, which comprise maize landraces in the first and second recurrent selection cycles, respectively.

\begin{tabular}{lcc}
\hline & \multicolumn{3}{c}{ Group I } \\
\hline Environment & Crop Year & Cities \\
\hline E1 & $2002 / 2003$ & Palmeira-PR \\
E2 & $2002 / 2003$ & São Mateus do Sul-PR \\
E3 & $2002 / 2003$ & Bituruna-PR \\
E4 & $2003 / 2004$ & Irineópolis-SC \\
E5 & $2003 / 2004$ & Palmeira-PR \\
E6 & $2003 / 2004$ & São Mateus do Sul-PR \\
E7 & $2003 / 2004$ & Cruz Machado-PR \\
E8 & $2003 / 2004$ & Fernandes Pinheiro-PR \\
\hline \multicolumn{3}{c}{ Group II } \\
\hline E9 & $2004 / 2005$ & Palmeira-PR \\
E10 & $2004 / 2005$ & Fernandes Pinheiro-PR \\
E11 & $2004 / 2005$ & Cruz Machado-PR \\
E12 & $2004 / 2005$ & Londrina-PR \\
E13 & $2005 / 2006$ & Rio Azul-PR \\
E14 & $2005 / 2006$ & Bituruna-PR \\
E15 & $2005 / 2006$ & Irineópolis-SC \\
\hline
\end{tabular}

Source: Elaboration of the authors.
Adaptability and stability parameters were estimated by the Eberhart and Russell (1966) methodology, the Cruz, Torres e Vencovsky (1989) methodologies described by Cruz, Regazzi e Carneiro (2004), the Annicchiarico (1992) methodology introduced by Schmildt and Cruz (2005), which considers only the reliability index $\left(\mathrm{I}_{\mathrm{i}}\right)$, and the Lin and Binns (1988) methodology described by Gonçalves et al. (1999). Adaptability and stability parameters for each method were obtained by the GENES program (CRUZ, 2001).

\section{Results and Discussion}

Joint analysis of variance tests demonstrated that there were significant effects of all sources of variation in the two groups that were evaluated (Table 2). The ratio between the largest and smallest mean square was 6.42 for group I and 2.63 for group II. The coefficient of variation (CV) was $18.42 \%$ for group I and $16.86 \%$ for group II, indicating that the experiments were accurate. These results demonstrate that there were significant differences among varieties in each environment, among environments and among the performances of the varieties due to environmental variations. The best environments for grain yields were Irienópolis, Palmeira and São Mateus do Sul in the 2003/2004 crop year, the Fernandes Pinheiro in the 2004/2005 crop year and Rio Azul in the 2005/2006 crop year (Table 3). However, there were no significant effects of treatments in these environments, suggesting that an unfavorable environment promoted cultivar adaptation. 
Table 2. Mean squares of the joint analyses of variance for grain yield $\left(t \mathrm{th}^{-1}\right)$ and coefficients of variation (\%) and means for groups I and II, which are based on analyses of landraces in eight and seven environments, respectively.

\begin{tabular}{lccccc}
\hline Source of variation & \multicolumn{3}{c}{ Group I } & & \multicolumn{2}{c}{ Group II } \\
\cline { 2 - 3 } \cline { 5 - 6 } Block/Environment & d.f. & Mean Square & & d.f. & Mean Square \\
Environments & 24 & $4.8404^{* *}$ & & 21 & $4.3489^{* *}$ \\
Varieties & 7 & $95.980^{* *}$ & & 6 & $18.975^{* *}$ \\
Varieties x environments & 12 & $4.4445^{* *}$ & & 12 & $3.6409^{* *}$ \\
Error & 84 & $0.9685^{* *}$ & & 72 & $0.9613^{* *}$ \\
\hline CV\% & 285 & 0.6022 & & 252 & 0.3801 \\
Mean & & 18.42 & & 3.66 \\
\hline
\end{tabular}

$* * p<0.01$ (F-test).

Source: Elaboration of the authors.

The presence of a genotypes $\mathrm{x}$ environmental interactions determines the varieties that will be recommended for a particular region (RIBEIRO; RAMALHO; FERREIRA, 2000). The varieties Macaco and Amarelão (group I) and Caiano and Carioca (group II) showed the best yields in the tested environments, outperforming the control variety BR106 (Table 3). Thus, because they performed the best in the widest range of environments, these four landraces, as well as the Palha Roxa landrace, are the most highly recommended for the south central region of Paraná,

There are differences between the genotypes in groups I and II (Table 4 and 5), and there were changes in landrace yields between the groups. However, in both groups, Macaco, Amarelão, Caiano, Carioca and Palha Roxa remained among the most productive, as they did not differ among themselves according to the Tukey test $(\mathrm{P}<0.05)$, with average productivities $\left(\beta_{0}\right)$ between 5.07 and $4.38 \mathrm{t} \mathrm{ha}^{-1}$ in group I and 4.15 and $3.79 \mathrm{t} \mathrm{ha}^{-1}$ in group II. This result demonstrates the important role of adaptability and stability studies in identifying productive, adaptable and stable varieties for family agricultural systems.

The methodology of Eberhart and Russell (1966) uses the linear regression coefficient $\left(\beta_{\mathrm{i}}\right)$ as the adaptability parameter and the regression deviation variance as the stability parameter $\left(\sigma_{\mathrm{di}}{ }^{2}\right)$. Regression deviations are dispersion measures around the regression line and are associated with the performance replicability of materials in the environments. The methodology of Cruz, Torres e Vencovsky (1989) allows for the identification of materials that are adaptable to unfavorable conditions $\left(\beta_{1 \mathrm{i}}\right)$ and that respond well to environmental improvements $\left(\beta_{1 \mathrm{i}}+\beta_{2 \mathrm{i}}\right)$.

Lin and Binns (1988) proposed a superiority measure, given by the value of $\mathrm{P}_{\mathrm{i}}$ for each genotype. According to Gonçalves et al. (1999), the Lin and Binns methodology (1988) presupposes a search for the material with the best performance in most of the environments. Annicchiarico's methodology (1992) takes into consideration genotype yield in the environments assessed and performance variation among environments. This method provides a reliability index $\left(\mathrm{I}_{\mathrm{i}} \%\right)$ for a determined material. 


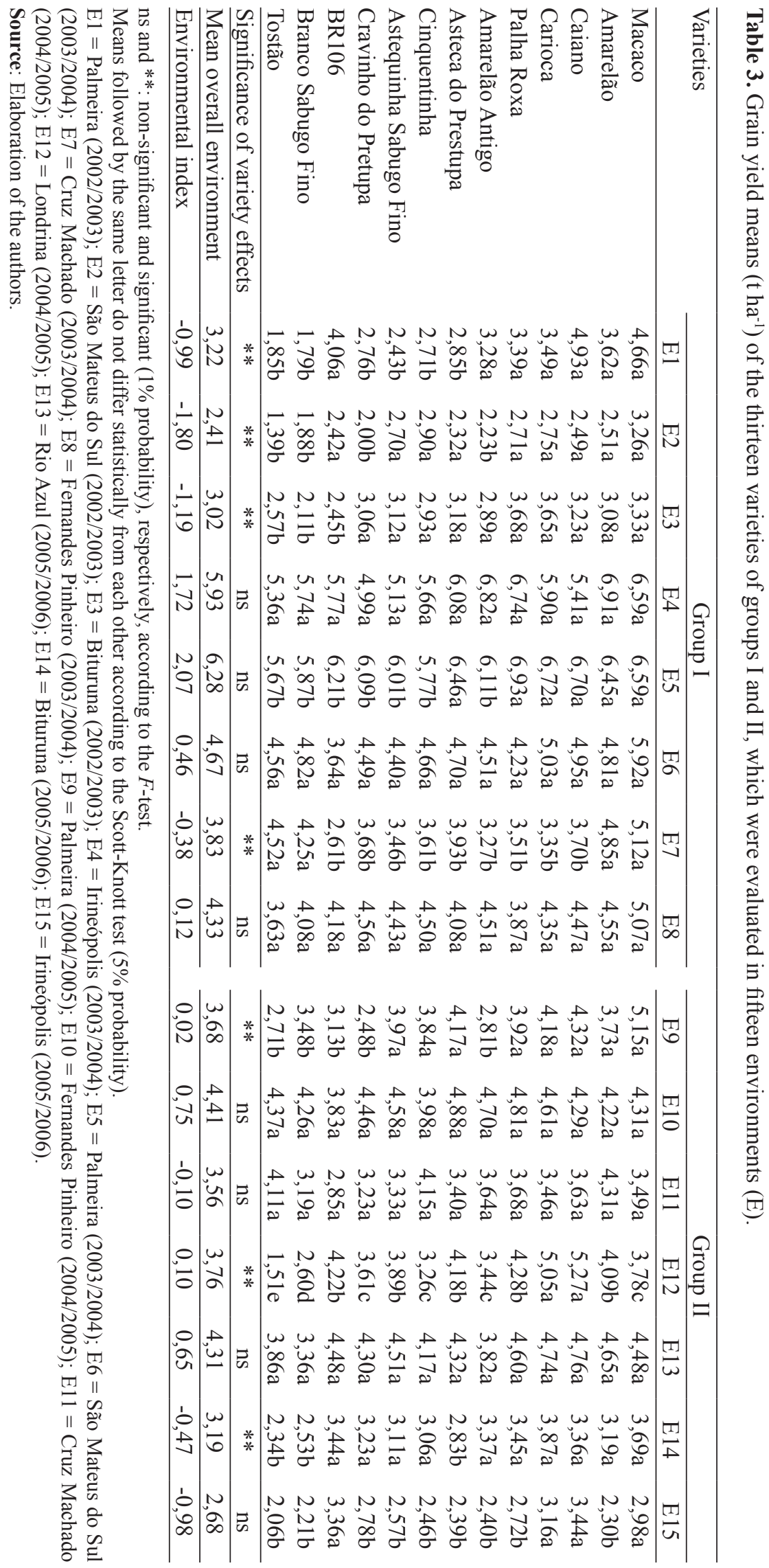




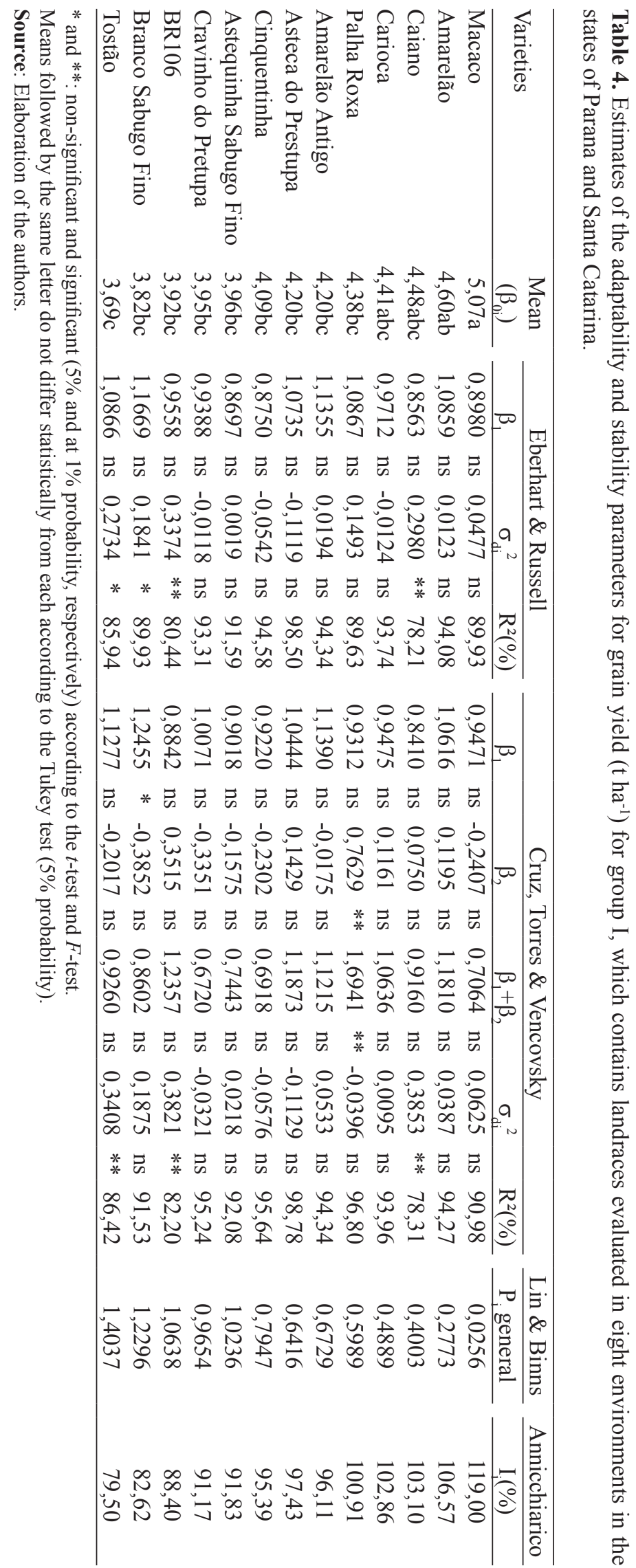




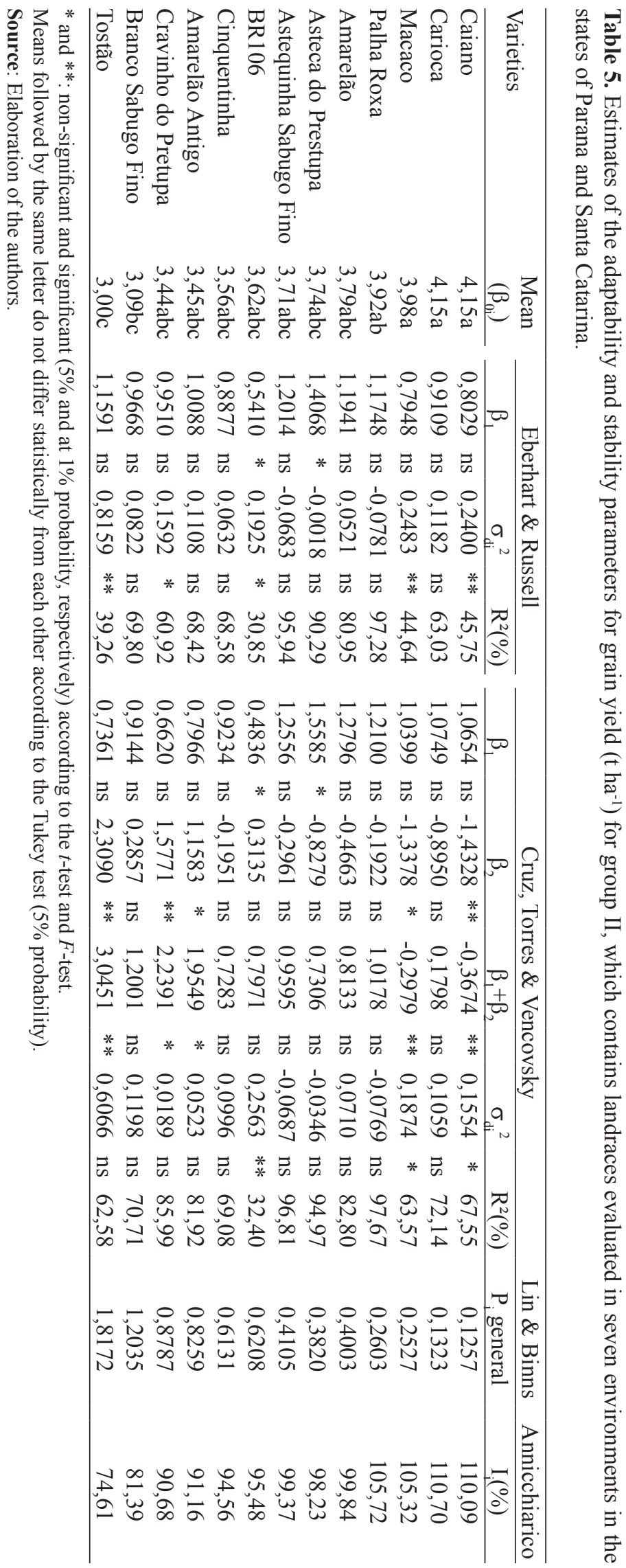


Adaptability and stability analyses for group I are considered first (Table 4). Using the Eberhart and Russell (1966) method, the varieties presented $\beta_{1}$ values statistically equal to one, indicating wide adaptability and responsiveness to environmental improvement.

Among the landrace varieties, only the Caiano, Branco Sabugo Fino and Tostão showed significant $\sigma_{\mathrm{di}}^{2}$ deviation from zero, suggesting unpredictable behavior due to environmental stimulus. However, this result does not limit the use of these two last varieties because they nevertheless presented determination coefficient values $\left(\mathrm{R}^{2}\right)$ above $85 \%$, as recommended by Oliveira, Souza Sobrinho e Fernandes (2004) for maize crops. The determination coefficient reflects the degree of adjustment of the model to the yield means observed for each of the materials assessed. Fonseca Junior (1999) stresses that the $\mathrm{R}^{2}$ can be considered a more impartial predictability measure than the regression deviations variance itself.

Using the methodology of Cruz, Torres e Vencovsky (1989), the Palha Roxa variety showed adaptability to unfavorable environments $\left(\beta_{1 \mathrm{i}}=\right.$ $1)$, responsiveness to environmental improvement $\left(\beta_{1 \mathrm{i}}+\beta_{2 \mathrm{i}}>1\right)$ and highly predictable behavior. The other varieties showed identical behavior in both favorable and unfavorable environments $\left(\beta_{2 \mathrm{i}}=0\right)$.

The methodology of Cruz, Torres e Vencovsky (1989) better adjusted the regression deviations in two straight-line segments, reducing the deviation in relation to the linear regression with negative environment indexes. Overall, however, the results obtained from the Eberhart and Russell (1966) and Cruz, Torres e Vencovsky (1989) methodologies were consistent for most varieties.

Using the Lin and Binns (1988) methodology, the Macaco and Amarelão varieties stood out for showing the lowest estimates for $\mathrm{P}_{\mathrm{i}}$. The lower the $\mathrm{P}_{\mathrm{i}}$, value the higher a genotype's capacity to be among the best and to perform well in the largest number of environments (ARIAS; RAMALHO;
FERREIRA, 1996).

Reliability indexes $\left(\mathrm{I}_{\mathrm{i}} \%\right)$ estimated by the Annicchiarico (1992) method showed that the variety which is the least risky to adopt is the Macaco variety, which had a reliability index (19\%) that was superior to that of the other varieties. The Amarelão, Caiano and Carioca also had superior indexes of $6,57 \%, 3,10 \%$ and $2,86 \%$, respectively.

Table 5 shows the calculated adaptability and stability parameters for group II. The varieties considered ideal by the Eberhart and Russel (1966) methodology were Palha Roxa, Amarelão and Astequinha Sabugo Fino because they had the highest means $\left(\beta_{0}\right)$, a wide adaptability $\left(\beta_{1}=1\right)$ and predictable behavior $\left(\sigma_{\mathrm{di}}^{2}=0\right)$. These varieties did not differ statistically from each other according to the Tukey test $(p<0.05)$.

Using the methodology of Cruz, Torres e Vencovsky (1989), the Caiano, Macaco, Amarelão Antigo, Cravinho do Prestupa and Tostão varieties responded well to improvements in environmental conditions $\left(\beta_{1 \mathrm{i}}+\beta_{2 \mathrm{i}}>1\right)$ and adjusted best to the bi-segmented regression analysis. These results are supported by their significantly reduced regression deviations $\left(\sigma_{\mathrm{di}}^{2}\right)$.

With both methodologies involving linear regressions, the control variety BR106 showed adaptability to unfavorable conditions and erratic behavior $\left(\mathrm{R}^{2}=30 \%\right)$ in group II and wide adaptability in group I. This cultivar has been observed to behave differently in different parts of the country, specifically in Minas Gerais State (HAMAWAKI; SANTOS, 2003), the Northeast (CARVALHO et al., 2005) and Paraná State (ALVES et al., 2006). The results obtained by the non-parametric methods of Lin and Binns (1988) and Annicchiarico (1992) also demonstrate the low stability and reliability of BR106 in the south central region of Parana, compared with the best performing landraces. Overall, the majority of the landraces assessed are competitive with the control BR 106 in the environments studied. 
In general, for the experimental varieties, different results were obtained with the four different methodologies. When the linear regression analyses were used the varieties had low yield, wide or condition-specific adaptability and predictable behavior. When the Lin and Binns (1988) and Annicchiarico (1992) methodologies were used, they showed less stable behavior due to environmental variations.

The landraces in the second cycle (group II) showed grain yield means ( $\mathrm{t} \mathrm{ha}^{-1}$ ) relatively lower than those observed for group I. This was due to the dry period the plants in the group II trials had to endure. In addition, there was a change in the relative position of varieties from the first to the second group. In both groups, however, the Amarelão, Caiano, Carioca, Macaco and Palha Roxa varieties were among the most productive, with no difference among themselves according to the Tukey test $(p<0,05)$.

Although the Group II trials took place in different environments from the group I trials, the adaptability and stability results were expected to be similar in the two groups, mainly due to improvement by recurrent selection. According to previously reported findings, however, group II underwent a great hydric deficit, which may have resulted in the different responses of the varieties in the two groups under adverse conditions. For a characteristic that is polygenic and highly influenced by the environment, grain yield shows great response variation. The Caiano, Carioca, Macaco and Palha Roxa varieties showed good yields, low $\mathrm{P}_{\mathrm{i}}$ values and the highest $\mathrm{I}_{\mathrm{i}} \%$ values. The Lin and Binns (1988) and Annicchiarico (1992) methodologies associated good yield with performance stability. Thus, the Macaco, Caiano, Carioca and Palha Roxa landrace varieties are recommended for family agricultural systems.

\section{Conclusions}

1. The majority of the maize landraces assessed are competitive with the control BR 106 in the environments studied.
2. The Macaco, Amarelão and Carioca varieties from group I, and Palha Roxa, Amarelão and Astequinha Sabugo Fino varieties from group II, are the most productive and widely adaptable and have the most predictable behavior; they are recommended thus for family agricultural systems.

3. This four methodologies adaptability and stability study is recommended because it is easy to implement and interpret.

\section{Acknowledgements}

The authors are grateful to CNPq and AS-PTA for their financial support and to the family farmers who work with us.

\section{References}

ALMEKINDERS, C. J. M.; LOUWAARS, N. P.; BRUIJIN, G. H. Local seed systems and their importance for an improved seed supply in developing countries. Euphytica, Netherlands, v. 78, n. 3, p. 207-216, 1994.

ALVES, S. J.; TOLEDO, J. F. F.; ARAÚJO, P. M.; GARBUGLIO, D. D. Stability and adaptability performance of different genetic classes of maize. Revista Brasileira de Milho e Sorgo, Sete Lagoas, v. 5, n. 2, p. 291-303, 2006.

ANNICCHIARICO, P. Cultivar adaptations and recommendation from alfafa trials in Northern Italy. Journal of Genetics and Breeding, Rome, v. 46, n. 1, p. 269-278, 1992.

ARAÚJO, P. M.; NASS, L. L. Characterization and evaluation of maize landraces. Scientia Agricola, Piracicaba, v. 59, n. 3, p. 589-593, 2002.

ARIAS, E. R. A.; RAMALHO, M. A. P.; FERREIRA, D. F. Adaptability and stability of maize cultivars evaluated in Mato Grosso do Sul State. Ciência e Agrotecnologia, Lavras, v. 20, n. 4, p. 415-420, 1996.

CARGNELUTTI FILHO, A.; PERECINI, D.; MALHEIROS, E. B.; GUADAGNIN, J. P. Comparison of adaptability and stability methods related to grain yield of maize cultivars. Bragantia, Campinas, v. 66, n. 4, p. 571-578, 2007.

CARVALHO, H. W. L.; CARDOSO, M. J.; LEAL, M. L. S.; SANTOS, M. X. dos; TABOSA, J. N.; SOUZA, E. M. Adaptability and stability of maize cultivars in northeast 
Brazil. Pesquisa Agropecuária Brasileira, Brasília, v. 40, n. 5, p. 471-477, 2005.

CECCARELLI, S. Specific adaptation and breeding for marginal conditions. Euphytica, Netherlands, v. 77, n. 3, p. 205-219, 1994.

CRUZ, C. D. Programa genes - versão windows: aplicativo computacional em genética e estatística. Viçosa, MG: UFV, 2001. 648 p.

CRUZ, C. D.; REGAZZI, A. J.; CARNEIRO, P. C. S. Modelos biométricos aplicados ao melhoramento genético. Viçosa, MG: UFV, 2004. v. 1, 390 p.

CRUZ, C. D.; TORRES, R. A. A.; VENCOVSKY, R. An alternative approach to the stability analysis proposed by Silva and Barreto. Revista Brasileira de Genética, Ribeirão Preto, v. 12, n. 2, p. 567-580, 1989.

EBERHART, S. A.; RUSSEL, W. A. Stability parameters for comparing varieties. Crop Science, Madson, v. 6, n. 1, p. 36-40, 1966.

FARIAS, F. J. C.; RAMALHO, M. A. P.; CARVALHO, L. P.; MOREIRA, J. A. N.; COSTA, J. N. Stability parameters proposed by Lin and Binns (1988) compared with the method of regression. Pesquisa Agropecuária Brasileira Brasília, v. 32, n. 4, p. 407-414, 1997.

FERREIRA, J. M.; MOREIRA, R. M. P.; TARDIN, J. M.; JANTARA, A. E. Fitomejoramiento participativo de variedades de maíz criollo: una experiencia en la Región Centro Sur de Paraná, Brasil. In: LABRADA, H. R.; ESPINOSA, M. M. H.; SOTOMAYOR, J. C. R. (Ed.). Fitomejoramiento participativo: los agricultores mejoran cultivos. La Habana, CUBA: Ediciones INCA, 2006. p. 197-219.

FONSECAJUNIOR, N. S. Interação genótipo x ambiente: aspectos biométricos. In: DESTRO, D.; MONTALVÁN, R. (Ed.). Melhoramento genético de plantas. Londrina: Ed. UEL, 1999. p. 141-178.

GONÇALVES, F. M. A.; CARVALHO, S. P. de; RAMALHO, M. A. P.; CORRÊA, L. A. Importance of cultivars $\mathrm{x}$ locations and cultivars $\mathrm{x}$ years interactions in maize evaluation in the "safrinha". Pesquisa Agropecuária Brasileira, Brasília, v. 34, n. 7, p. 11751181, 1999.

HAMAWAKI, O. T.; SANTOS, P. G. Adaptability and stability of maize genotypes evaluated by the regression model. Ciência Rural, Santa Maria, MG, v. 33, n. 2, p. 195-199, 2003.
LIN, C. S.; BINNS, M. R. A superiority measure of cultivar performance for cultivar x location data. Canadian Journal of Plant Science, Ottawa, v. 68, n. 1, p. 193-198, 1988.

MAURO, A. O. D.; CURCIOLI, V. B.; NÓBREGA, J. C. M.; BANZATO, D. A.; SEDIYAMA, T. Correlation measures between parametric and nonparametric stability in soybean. Pesquisa Agropecuária Brasileira, Brasília, v. 35, n. 4, p. 687-696, 2000.

MURAKAMI, D. M.; CARDOSO, A. A.; CRUZ, C. D.; BIZÃO, N. Considerations about two methodologies for the analysis of stability and adaptability. Ciência Rural, Santa Maria, MG, v. 34, n. 1, p. 71-78, 2004.

OLIVEIRA, J. S.; SOUZA SOBRINHO, F.; FERNANDES, S. B. V. Stratification of environments, adaptability and stability of commercial corn hybrids for silage in southern Brazil. Ciência Rural, Santa Maria, MG, v. 34, n. 4, p. 997-1003, 2004.

PATERNIANI, E.; NASS, L. L.; SANTOS, M. X. O valor dos recursos genéticos de milho para o Brasil: uma abordagem histórica da utilização do germoplasma. In: UDRY, C. W.; DUARTE, W. (Ed.). Uma história brasileira do milho: o valor dos recursos genéticos. Brasília, DF: Ed. Paralelo, 2000. p. 11-41.

PIMENTEL-GOMES, F. Curso de estatística experimental. São Paulo: Livraria Nobel Ed. Nobel, 2000. $468 \mathrm{p}$.

RIBEIRO, P. H. E.; RAMALHO, M. A. P.; FERREIRA, D. F. Adaptability and stability of maize genotypes under different environmental conditions. Pesquisa Agropecuária Brasileira, Brasília, v. 35, n. 11, p. 22132222, 2000.

SAS Institute Inc. Proprietary software release V 6.12 for windows. Cary, North Carolina, USA, 2005.

SCAPIM. C. A.; OLIVIERA, V. R.; BRACCINI, A. L.; CRUZ, C. D.; ANDRADE, C. A. B.; VIDIGAL, M. C. G. Yield stability in maize (Zea mays L.) and correlations among the parameters of the Eberhart and Russel, Lin and Binns and Huehn models. Genetics and Molecular Biology, Ribeirão Preto, v. 23, n. 2, p. 387-393, 2000.

SCHMILDT, E. R.; CRUZ, C. D. Analysis of adaptability and stability of maize by the methods of Eberhart and Russel (1966) and Annicchiarico (1992). Revista Ceres, Viçosa, v. 52, n. 299, p. 45-58, 2005.

VENCOVSKY, R.; BARRIGA, P. Genética biométrica no fitomelhoramento. Ribeirão Preto: Ed. Sociedade Brasileira de Genética, 1992. 486 p. 